\title{
Safety and efficacy of a pre-wrkout dietary supplement with and without synephrine
}

\author{
R Dalton ${ }^{1}$, YP Jung ${ }^{1 *}, C$ Rasmussen ${ }^{1}$, P Murano ${ }^{2}$, CP Earnest ${ }^{1,3}$, RB Kreider ${ }^{1}$ \\ From The Twelfth International Society of Sports Nutrition (ISSN) Conference and Expo \\ Austin, TX, USA. 11-13 June 2015
}

\begin{abstract}
Background
A number of nutritional strategies have been developed to optimize nutrient delivery prior to exercise. As a result, a number of pre-workout supplements have been developed to increase energy availability, promote vasodilation, and/or positively affect exercise capacity. The purpose of this study was to examine the safety and efficacy of a preworkout dietary supplement with and without synephrine.
\end{abstract}

\section{Methods}

In a double-blind, crossover, randomized and placebocontrolled manner; 25 apparently healthy and recreationally active men and women $(21.76 \pm 3.00 \mathrm{yr}, 15.24 \pm 5.26 \%$ fat, $25.09 \pm 3.03 \mathrm{~kg} / \mathrm{m}^{2}$ ) had the first blood donation after 10-12 hours fasting, and then after 2 hours of a preworkout supplement ingestion, participants had the second blood donation. Participants ingested in a randomized and counterbalanced manner a dextrose flavored placebo (P); a pre-workout supplement (PWS) containing $3 \mathrm{~g}$ beta alanine, $2 \mathrm{~g}$ creatine nitrate, $2 \mathrm{~g}$ arginine AKG, $300 \mathrm{mg} \mathrm{N}$-acetyl tyrosine, $270 \mathrm{mg}$ caffeine, $15 \mathrm{mg}$ Mucuna pruriens; or, the PWS with $20 \mathrm{mg}$ synephrine (PWS+S). Participants repeated the experiment after a one week washout period with the alternate supplements in a randomized and counterbalanced manner. Data were analyzed by repeated measure ANOVA and presented as means $(95 \% \mathrm{CI})$ delta change from baseline.

\section{Results}

Delta analysis revealed significant differences among groups in mean change in blood urea nitrogen (BUN) (unit conversion to $\mathrm{mg} / \mathrm{dl}$ by $\mathrm{mmol} / \mathrm{l} \times 2.8011$ ): $\mathrm{P}$ $(-1.51 \mathrm{mg} / \mathrm{dl} ;-2.26,-0.78)$, PWS $(-2.26 \mathrm{mg} / \mathrm{dl} ;-2.99,-1.54)$,

\footnotetext{
* Correspondence: peterjung@hlkn.tamu.edu

${ }^{1}$ Exercise \& Sport Nutrition Lab, Texas A\&M University, College Station, TX USA

Full list of author information is available at the end of the article
}

and PWS +S (-0.56mg/dl; -1.28, 0.14), creatinine (CRE) (unit conversion to $\mathrm{mg} / \mathrm{dl}$ by $\mu \mathrm{mol} / \mathrm{L} \times 0.0113$ ): P $(0.05 \mathrm{mg} / \mathrm{dl} ; 0.01,0.10)$, PWS $(0.14 \mathrm{mg} / \mathrm{dl} ; 0.09,0.19)$, and PWS +S $(0.14 \mathrm{mg} / \mathrm{dl} ; 0.09,0.18)$. An overall Wilks' Lambda time $(\mathrm{p}<0.01)$ and time $\times$ group $(\mathrm{p}<0.01)$ interactions for BUN, CRE and the ratio of BUN/CRE (BCr), and Greenhouse-Geisser univariate analysis for BUN, CRE and $\mathrm{BCr}(\mathrm{p}<0.01)$ were found. Wilks' Lambda analysis revealed a significant time effect $(\mathrm{p}<0.05)$ of alkaline phosphatase (ALP), aspartate amino transferase (ALT), and alanine amino transferase (AST), and of creatine kinase (CK) and lactate dehydrogenase (LDH), with no time $\times$ group interactions $(\mathrm{p}>0.05)$. MANOVA Greenhouse-Geisser univariate analysis revealed significant changes over time for ALP, ALT and AST $(\mathrm{p}<0.01)$, and CK and LDH $(\mathrm{p}<0.01)$. Delta analysis revealed significant differences among groups in mean change in total cholesterol (CHOL): P $(0.31 \mathrm{mmol} / \mathrm{L} ; 0.12,0.50)$, PWS $(-0.16 \mathrm{mmol} / \mathrm{L} ;-0.35,0.02)$, and PWS $+\mathrm{S}(0.31 \mathrm{mmol} / \mathrm{L}$; $0.12,0.50)$. An overall Wilks' Lambda time $(\mathrm{p}<0.01)$ and time $\times$ group $(\mathrm{p}<0.01)$ interactions for $\mathrm{CHO}, \mathrm{HDL}-\mathrm{C}$, LDL-C and triglyceride (TAG), and Greenhouse'Geisser univariate analysis for CHO, HDL-C, and LDL-C ( $<<$ 0.01 ) were found. Delta analysis revealed significant differences among groups in mean change in glucose: $\mathrm{P}$ (0.60mmol/L; 0.21, 0.99), PWS $(0.77 \mathrm{mmol} / \mathrm{L} ; 0.39,1.15)$, and PWS $+\mathrm{S}(1.29 \mathrm{mmol} / \mathrm{L} ; 0.90,1.68)$. A significant time $\times$ group interactions $(\mathrm{p}<0.03)$ of glucose was found.

\section{Conclusion}

Ingesting a dietary PWS or PWS + S had minor affects within 3 hours, similar to $P$, on kidney function, liver enzymes, blood lipid levels, muscle enzymes, and blood sugar levels. These findings are in agreement with other studies testing similar ingredients. 


\section{Acknowledgements}

Supported by Nutrabolt International, Inc. (Bryan, TX).

\section{Authors' details}

'Exercise \& Sport Nutrition Lab, Texas A\&M University, College Station, TX, USA. ${ }^{2}$ Institute for Obesity Research \& Program Evaluation, Texas A\&M University, College Station, TX, USA. ${ }^{3}$ Nutrabolt International Inc., Bryan, TX, USA.

Published: 21 September 2015

doi:10.1186/1550-2783-12-S1-P5

Cite this article as: Dalton et al.: Safety and efficacy of a pre-wrkout

dietary supplement with and without synephrine. Journal of the

International Society of Sports Nutrition 2015 12(Suppl 1):P5.

Submit your next manuscript to BioMed Central and take full advantage of:

- Convenient online submission

- Thorough peer review

- No space constraints or color figure charges

- Immediate publication on acceptance

- Inclusion in PubMed, CAS, Scopus and Google Scholar

- Research which is freely available for redistribution

Submit your manuscript at www.biomedcentral.com/submit 